\title{
粉乳, 血清學的研究
}

京都帝國大學醫學部微生物學敉室（主任 木村教授）

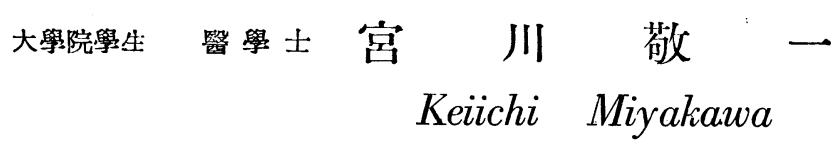

（昭和11年 5 月 26 日受付)

\section{【㐫容抄錄】}

本編 =於テ, 現今施行セラルル代表的粉乳製法タ几噴第式及ビ圆筒式二依几粉学，血清學的研

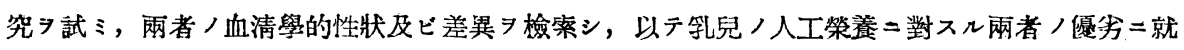
テ血清學的見地ョリ論ジタリ.

目次

緒 葍

第 1 章 筫驗材料兹=方法

甲 筫驗材料

1 抗原

2 免疫血清

乙 宣羷方法

1 沈降反應試驗

2 補觶結合反㣹試驗

第 2 章 實驗成績

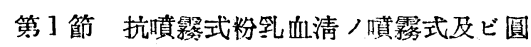
筒式粉乳 = 對ス几反管

第 2 節 抗圆筒式粉乳血清/噴筼式及ビ圆 笠式粉乳 $=$ 對スル反應

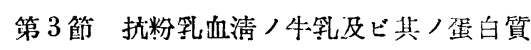
ふらくちおーん對ス几反㣹

第 1 項 抗墳霧式粉乳血清/牛乳及ビ其

蛋白質ふらくちおーん二對ス
几反應

第 2 項 抗圆筒式粉乳血清/牛乳及ビ其 ノ蛋白質ふらくちおーん=對 几反應

第 4 節 抗牛乳血清/噴䨏式及ビ圆简式粉 乳 $=$ 對スル反應

第 5 節 抗牛かぜいん血清 噴箈式及ビ圆 筒式粉乳二對スル反應

第 6 節 抗牛乳清血清ノ噴霧式及ビ圆筒式 粉乳二對スル反應

第 7 節 抗尜沸牛乳血清 噴霧式及ビ圆筒 式粉乳二對 ス八反碓

第 8 節 抗噴䈻式粉乳及ビ 抗圓㟢式粉乳血 清ノ牛血清二對スル反應

第 3 章 總括前二考按

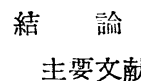

言

凡ッ人トシテ此ノ世二生习受ヶ, 慈愛深キ母ノ手=抱カレッッ, 天ノ恩惠トモ稱スべキ母 乳フ心行クママ吸飲シテ, 健康二發育シ得ル乳兒二モ優リテ幸福ナルハ尠カルベン: 然ルニ 輓近時代ノ進步發達二伴ヒ，世相漸ク複雜化シ，婦女子，職業戰線二進出スルモノ多斗 數 $フ ル=$ 及ビ, 母乳榮養 $=$ 代ブル $=$, 異種乳汁 
(1118)

粉乳, 血清學的磝究

一般二乳兒 八八工榮食 $/$ 目的ニ八牛乳及ビ山羊乳供ゼル. 然レドモ, 現今僻陬つ地二在 リテハ未ダ良好ナル新鮮乳ヨ入手スルコト難ク, 幾多ノ不便ヨ免レズ. 從ツテ運搬二便二シ テ, 腐敗シ難ク, 如何ナル邀鄙ノ地二於テモ, 入手容易ニシテ且常二新鮮乳卜同樣ナル乳汁

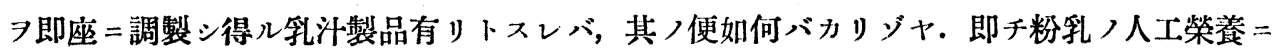
用ヒラルルニ至リシ所以ナリ.

粉乳 $=$ 依ル人工榮飬漸ク盛ナル $=$ 及ビ, 其/化學的組成, 練菌, 含有量, Vitamin，含 有量, 粉乳ノ使用法及ビ製品ノ新舊 鑑別等種々ナル業績踵シ接シテ發表セラレタリ。然ル 二粉乳, 血清學的研究二至リテ八識者, 注目スル所トナラズシテ, 僅カ = Schlossberger(1) 及ビ福田 (2) 業績ヨ算スルノミ。

余八本編 =於テ, 現今施行七ラルル代表的粉乳製法夕ル噴蓩式及ビ圆筒式 $=$ 低ル粉乳, 血

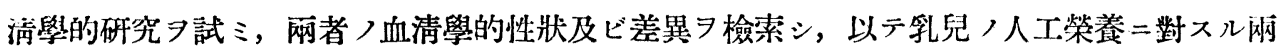
者ノ傮劣二就テ血清學的見地ョリ論ボント欲ス。

\section{第 | 章 實驗材料並二方法}

\section{甲 實 驗 材 料}

I 抗 原

噴霧式粉乳）代表トシテ $\mathrm{Me}$ (國虐) 及ビ $\mathrm{K}$ (舶來) フ選ビ，圓筒式粉乳，代表トシテ Mo (國產) 及ビ L (舶來) 7 用ヒタリ.

粉乳入製法, 製造技術及ビ添加物等ニヨリテ其ノ組成ヨ設ゲザル可カラズ. 余八上述ノ各 種粉乳，總窒菜量 7 Kjeldahl 氏法二依リテ測定シテ, 總蛋白質量 $=$ 換算七シ $=, \mathrm{Me}>24$.

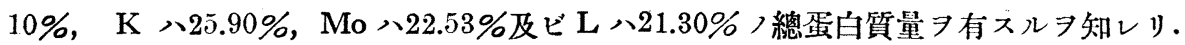

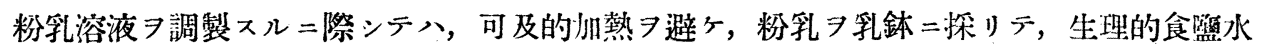

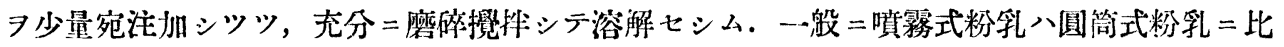
シテ溶解容易ナルラ覺エタリ。

斯クシテ調製七ル粉乳浴液入余，測定七シ牛乳 總蛋白質量 (3.55\%) 》抗原，原液卜定 メ, 之习規集トシテ 25, 50, 100，200倍等〉稀釋液ヨ作レリ.

牛乳ヨリかぜいん及ビ乳清ノ 2 蛋白質ふらくちお゙ーんす分離ンテ抗原二使用セリ．其ノ分 離法二關シテハ既＝詳述セリ(3). 而テかぜいん及ビ乳活溶液八乳汒中二会有七ラルル絶對 量ヨ原液トシテ起算ヒリ。

\section{2 免 疫 血 清}

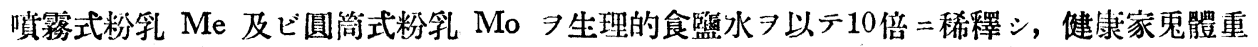




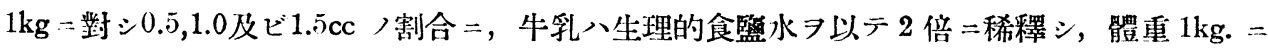

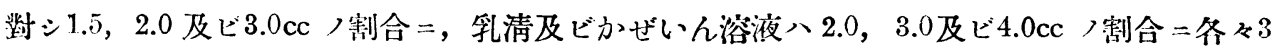

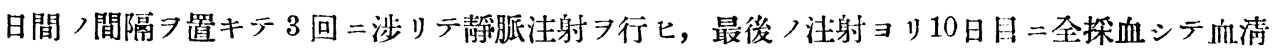
习分離ス。沈降反應トシテハ生, 滥习補體結合反應用トシテハ $56^{\circ} \mathrm{C} 30$ 分加溫シテ非働性トナ ヒジノフ使用ス.

\section{乙 筫 驗 为 法}

沈降父隹及ビ補體結合反應二依ル。

\section{1）沈降反隹試 驗}

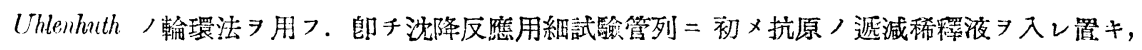
然儿後ニ極メテ細キびハつつとヨ以テ免疫血清习吸引シ,ソノ尖端ヨ拭キ取リ, 速カ二試驗管底二

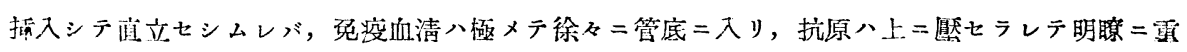

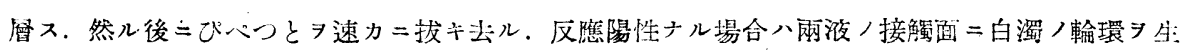

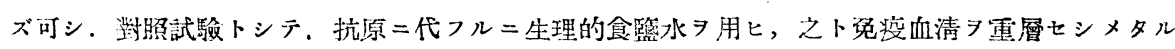

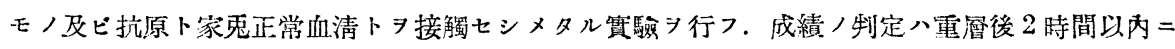

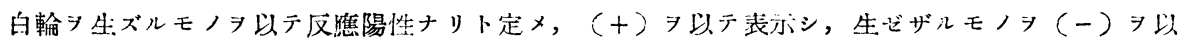
テ示ス.

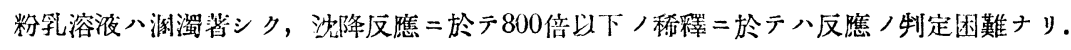

\section{2）補體結合区碓試驗}

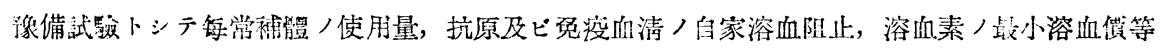

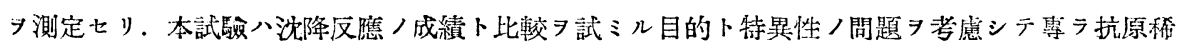

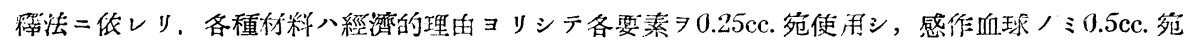
加フ.

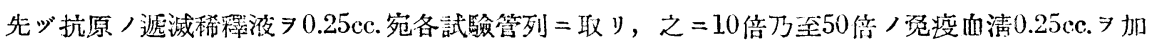
一, 更 $=5$ 匹万至6匹几海㩧ヨリ探血シ，其ノ力筫 シ補體トシテ $0.25 \mathrm{cc}$.宛加フ.

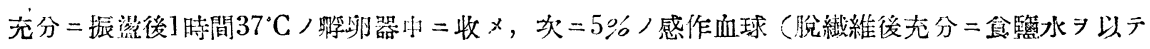

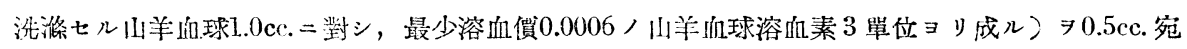

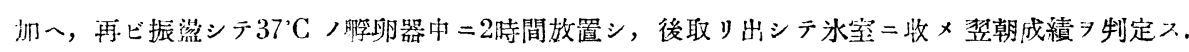

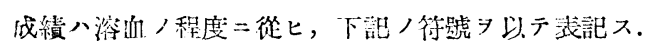
K. 完奎溶血.
fk. 殆ド完全溶血.
st. 强度溶血.
in. 中等度溶血.
w. 弱度溶血.
$\mathrm{sp}$. 痕跡溶血.
spch. 殆ド完全溶血阻止,
O. 完全溶血阳止.

\section{第 2 章 篔 驗 成 績}

第 1 節 抗噴霧式粉乳血清八噴霧式及ビ圓筒式粉乳二 對スッ反應 
第 1 表 抗 $\mathrm{Me}$ 粉乳血清， $\mathrm{Me}, \mathrm{K}, \mathrm{Mo}$ 及ビ $\mathrm{L}$ 粉乳=對スル沈降反應

\begin{tabular}{|c|c|c|c|c|c|c|}
\hline $\begin{array}{l}\text { 稀賈倍數 } \\
\text { 抗原 }\end{array}$ & 1600 & 3200 & 6400 & 12800 & 25600 & 51200 \\
\hline $\mathrm{Me}$ & + & + & + & + & - & - \\
\hline $\mathrm{K}$ & + & + & + & + & \pm & - \\
\hline Mo & + & + & + & + & - & - \\
\hline $\mathrm{L}$ & + & + & + & + & - & - \\
\hline
\end{tabular}

第 1 裴. 沈降反應二於テ抗 $\mathrm{Me}$ 粉乳血清入, Mə, $\mathrm{K}, \mathrm{Mo}$ 及 反隹习是入。

第 2 表 抗 $\mathrm{Me}$ 粉乳血溜, Me, $\mathrm{K}, \mathrm{Mo}$ 及ビ $\mathrm{L}$ 粉乳二龂スル補體結合反應

\begin{tabular}{|c|c|c|c|c|c|c|c|c|c|c|}
\hline 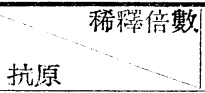 & 200 & 400 & 800 & 1600 & 3200 & 6490 & 12800 & 25600 & $512: 0$ & 102400 \\
\hline $\mathrm{Me}$ & O & $\mathrm{O}$ & 0 & $\mathrm{O}$ & 0 & 0 & O & 0 & $\mathrm{fk}$ & K \\
\hline $\mathrm{K}$ & O & 0 . & 0 & 0 & O & O & O & 0 & $\mathrm{~K}$ & K \\
\hline Mo & 0 & O & 0 & $\mathrm{O}$ & 0 & 0 & 0 & $\mathrm{sp}$ & K & $\mathrm{K}$ \\
\hline L & O & $\mathrm{O}$ & O & $\mathrm{O}$ & O & $\mathrm{O}$ & O & $\mathrm{O}$ & $\mathrm{fk}$ & $\mathrm{K}$ \\
\hline
\end{tabular}

第 2 表. 補體結合反應二於テ，抗 $\mathrm{Me}$ 粉乳血清八 $\mathrm{Me}, \mathrm{K}$ 及ビ $\mathrm{L}=$ 對シテ略々同程度， 反應习呈シ, Mo 二對シテハ稍々低度ノ反應习見ル.

上述ノ成績习通覽スル 圓筒式粉乳二峷シテ略々同程度，反應 7 呈ス.

第 2 筐 抗圓筒式粉乳血清, 噴霧式及ビ圓筒式粉乳

$$
\text { 二噛スル反應 }
$$

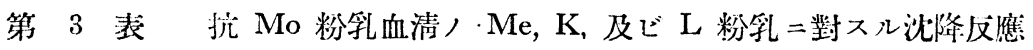

\begin{tabular}{|c|c|c|c|c|c|c|}
\hline 抗原 & 1600 & 3200 & 6400 & 12800 & 25600 & 51200 \\
\hline $\mathrm{Me}$ & + & + & + & + & - & - \\
\hline $\mathrm{K}$ & + & + & + & + & \pm & - \\
\hline Mo & + & + & + & + & - & - \\
\hline $\mathrm{L}$ & + & + & + & + & + & - \\
\hline
\end{tabular}

第 3 表. 沈降反應二於テ，抗 Mo 粉乳血活ハ Me 及ビ Mo =對活テテハ 12,800 倍二於テK 及ビ $\mathrm{L}=$ 對シテハ25.600倍二於テ反應ス。

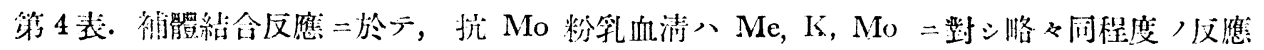

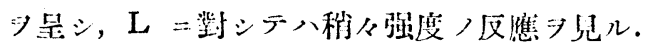


第 4 表 抗 Mo 粉乳血清, $\mathrm{Me}, \mathrm{K}, \mathrm{Mo}$ 及ビ $\mathrm{L}$ 粉乳 $=$ 對スル 補顝結合反應

\begin{tabular}{|c|c|c|c|c|c|c|c|c|c|c|}
\hline 抗原 & 200 & 400 & 800 & 1600 & 3200 & 6400 & 12800 & 25600 & 51200 & 1024 \\
\hline $\mathrm{Me}$ & 0 & 0 & 0 & O & $O$ & 0 & sp & $\mathrm{st}$ & K & $\mathrm{K}$ \\
\hline $\mathrm{K}$ & 0 & O & 0 & 0 & O & $O$ & spch & $\mathrm{w}$ & $f k$ & $\mathrm{~K}$ \\
\hline Mo & O & O & 0 & 0 & 0 & 0 & spch & K & K & K \\
\hline $\mathrm{L}$ & 0 & 0 & 0 & 0 & 0 & 0 & O & spch & st & K \\
\hline
\end{tabular}

上.述，成緽二低レバ，沈降反應及ビ補鰾結合反應二於テ，抗圓筒式粉乳向清八喷蓩式及ビ

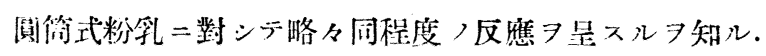

第 3 節 抗粉乳血清ノ牛乳及ビ其ノ蛋白質ふらくらおーん (かせ心ん及ビ学清) 二對スル反應

第 I 項 抗噴霧式粉乳血清ノ牛乳及ビ其ノ袋白質ふらく

$$
\text { らおーん二對スル反應 }
$$

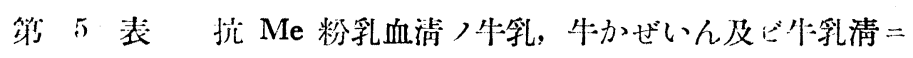
對スル沈降反應

\begin{tabular}{|c|c|c|c|c|c|c|c|c|c|c|c|c|}
\hline 抗原 & 傃倍數 & 50 & 100 & 200 & 400 & 800 & 1600 & 3200 & 6400 & 12800 & 25600 & 51200 \\
\hline 牛 & 乳 & + & + & + & + & + & + & + & + & + & + & - \\
\hline かぜい & h & + & + & + & + & + & + & + & + & + & + & - \\
\hline 乳 & 清 & + & + & + & + & + & - & - & - & - & - & - \\
\hline
\end{tabular}

第5表. 沈降反應二於テ, 抗 $\mathrm{Me}$ 粉乳血清八牛乳及ビかぜいん=對シテ同程度二反碓入 レドモ，乳清二對シテハ著シク低度ナル反應フ呈ス。

第 6 表 抗 $\mathrm{Me}$ 粉乳血清ノ牛乳かぜいん及ビ牧乳清 = 数スル補艠結合反應

\begin{tabular}{|c|c|c|c|c|c|c|c|c|c|c|c|}
\hline 抗原 & 罢倍數 & 50 & 100 & 200 & 490 & 800 & 1600 & 3200 & $64: 00$ & 12800 & 25600 \\
\hline 4 & 乳 & 0 & 0 & o & O & 0 & 0 & O & spch & $\mathrm{st}$ & $\mathrm{K}$ \\
\hline ふぜい & h & o & 0 & O & 0 & 0 & $\mathrm{O}$ & O & spch & $\mathrm{st}$ & $\mathrm{fk}$ \\
\hline 乳 & 洅 & 0 & $\mathrm{~m}$ & $\mathrm{fk}$ & K & K & K & K & K & K & K \\
\hline
\end{tabular}

第 6 表. 補體結合反應二於テ, 抗 $\mathrm{Me}$ 粉乳血清入牛乳及ビかぜいん=對シテ略々同程度 つ反應习是スレドモ，乳清二對シテ極ハメテ低度ナル反應习是ス.

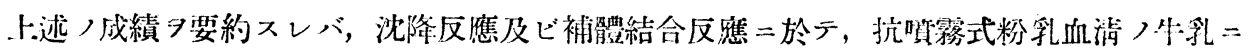


對スル反應八其，蛋白質ふらくちお゙ーんノ1ナルかぜいんニヨリデ略《代表ヒラルルモノニ シデ，乳琶八殆ド關與セザルモノナル事习知ル。

第 2 項 抗圓筒式粉乳血清ノ牛乳及ビ其ノ蛋白質

$$
\text { ふらくちおーんニ對スル反應 }
$$

第 7 裴 抗 Mo 粉乳血湔ノ牛乳，かぜいん及ビ乳湆二對スル沈降反應

\begin{tabular}{|c|c|c|c|c|c|c|c|c|c|c|c|}
\hline $\begin{aligned} & \text { 稀釋倍數 } \\
& \text { 抗原 }\end{aligned}$ & 50 & 100 & 200 & 400 & 800 & 1600 & 3200 & 6400 & 12800 & 25600 & 51200 \\
\hline 牛 乳 & + & + & + & + & + & + & + & + & + & + & - \\
\hline ふぜ゙いん & + & + & + & + & + & + & + & + & + & + & - \\
\hline 乳清 & + & + & + & - & - & - & - & - & - & -- & - \\
\hline
\end{tabular}

第 7 表. 沈降反應二於ラ，抗 Mo 粉乳血清、作乳及ビかぜいん=對シテ同程度，文隹》 星スレドモ, 乳清二對シテハ遙カ二低度ナル反應ヨ是ス.

第 8 表 抗 Mo 粉乳血清)牛乳, かぜいん及ビ乳滓二 對ス儿補體結合反應

\begin{tabular}{|c|c|c|c|c|c|c|c|c|c|c|}
\hline $\begin{array}{l}\text { 稀䆁傍數 } \\
\text { 抗原 }\end{array}$ & 50 & 100 & 200 & 400 & 800 & 1600 & 3200 & 6400 & 12800 & 25600 \\
\hline 4 & o & 0 & o & 0 & 0 & 0 & O & O & O & $\mathrm{sp}$ \\
\hline かゼいん & 0 & 0 & 0 & 0 & 0 & o & 0 & 0 & spch & sp \\
\hline 铛 & $\mathrm{sp}$ & $\mathrm{m}$ & $\mathrm{K}$ & $\mathrm{K}$ & $\mathrm{K}$ & K & K & K & K & $\mathrm{K}$ \\
\hline
\end{tabular}

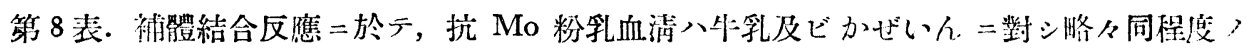

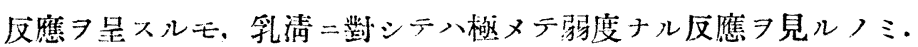

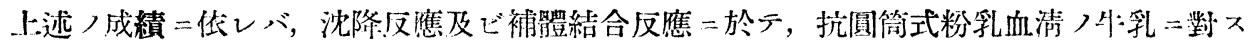
ル反應八其，蛋白質ふらくちお゙ーんノ1ナルかぜいんニ依リテ略ミ代表ヒラルルモノニシテ， 乳清ハ殆ド關與セザルモノナルフ知ル。

第 4 節 抗牛乳血清ノ噴霧式及ビ圆筒式粉乳

$$
\text { 二對スル反應 }
$$

\begin{tabular}{|c|c|c|c|c|c|c|c|}
\hline 抗原 & 870 & 1600 & 3200 & 6400 & 32800 & 25600 & 51200 \\
\hline $\mathrm{Me}$ & + & + & + & + & + & \pm & - \\
\hline $\mathrm{K}$ & + & + & + & + & + & .. & - \\
\hline Mo & + & + & + & + & + & - & - \\
\hline $\mathrm{L}$ & + & + & + & + & + & - & - \\
\hline
\end{tabular}

第 9 表 抗牛乳血清, $\mathrm{Me}, \mathrm{K}, \mathrm{Mo}$ 及 ビ $\mathrm{L}$ 粉乳=對スル沈降反應 


$$
\text { 宮川 敬紧 }
$$

第 9 表. 沈降反應 $=$ 於テ，抗牛乳血清入 $\mathrm{Me}, \mathrm{K}, \mathrm{Mo}$ 及ビ $\mathrm{L}=$ 對シテ略々同程度, 反應 쿶.

第 10 表 抗牛乳血清, $\mathrm{Me}, \mathrm{K}, \mathrm{Mo}$ 及ビ $\mathrm{L}$ 粉乳二對スル補體結合反應

\begin{tabular}{|c|c|c|c|c|c|c|c|c|c|c|}
\hline 稀粩倍數 & 100 & 200 & 400 & 800 & 1600 & 3200 & 6400 & 12800 & 25600 & 51200 \\
\hline Me & 0 & 0 & 0 & 0 & 0 & 0 & 0 & spch & $\mathrm{m}$ & $\mathrm{st}$ \\
$\mathrm{K}$ & 0 & 0 & 0 & 0 & 0 & 0 & $\mathrm{spch}$ & $\mathrm{w}$ & $\mathrm{m}$ & $\mathrm{m}$ \\
$\mathrm{Mo}$ & 0 & 0 & 0 & 0 & 0 & 0 & $\mathrm{spch}$ & $\mathrm{spch}$ & $\mathrm{m}$ & $\mathrm{st}$ \\
$\mathrm{L}$ & 0 & 0 & 0 & 0 & 0 & 0 & $\mathrm{~m}$ & $\mathrm{~m}$ & $\mathrm{fk}$ & $\mathrm{fk}$ \\
\hline
\end{tabular}

第10表. 補體結合反應二於テ，抗牛乳血满八 $\mathrm{Me}$ 二對シテ稍々高度 $=\mathrm{L}=$ 對シテハ稍々 低度二反應フ呈スレドモ，K 及ビ Mo =對スル反應二比シテ大差無シ。

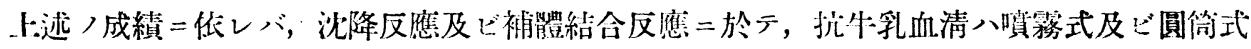

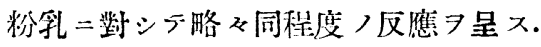

第 5 第 抗牛かせいん血清ノ噴霧式及ビ圓简式粉孚

$$
\text { ニ對スル反應 }
$$

\begin{tabular}{|c|c|c|c|c|c|c|c|}
\hline 抗原 & 800 & 1600 & 3200 & 6400 & 12800 & 25600 & 51200 \\
\hline $\mathrm{Me}$ & + & + & + & + & + & - & - \\
\hline $\mathrm{K}$ & + & + & + & + & + & - & - \\
\hline Mo & + & + & + & + & \pm & - & - \\
\hline $\mathrm{L}$ & + & + & + & + & + & - & - \\
\hline
\end{tabular}

第 11 裴 抗牛かぜいん血清

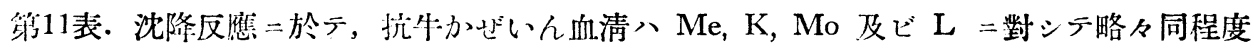
ノ反應习是ス.

第 12 表 抗牛がぜいん血浧, $\mathrm{Me}, \mathrm{K}, \mathrm{Mo}$ 及ビ $\mathrm{L}$ 粉乳=

\begin{tabular}{|c|c|c|c|c|c|c|c|c|c|}
\hline 抗原 & 100 & 200 & 400 & 800 & 1600 & 3200 & 6400 & 12800 & 25600 \\
\hline $\mathrm{Me}$ & 0 & 0 & 0 & 0 & 0 & 0 & $\mathrm{w}$ & $\mathbf{m}$ & $\mathrm{m}$ \\
\hline K & 0 & 0 & 0 & O & O & spch & $\mathrm{m}$ & $\mathrm{m}$ & $\mathrm{fk}$ \\
\hline $\mathrm{L}$ & O & 0 & 0 & 0 & 0 & O & $\mathrm{m}$ & $\mathrm{st}$ & $\mathrm{fk}$ \\
\hline Mo & O & o & 0 & 0 & 0 & o & $\mathrm{fk}$ & $\mathrm{K}$ & $\mathrm{K}$ \\
\hline
\end{tabular}
對スル補體結合反應

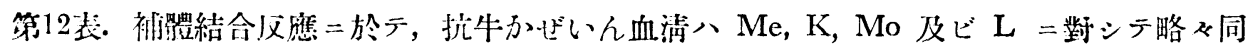


(1121)

粉乳, 吹清學的硎觉

程度二反應 $又$.

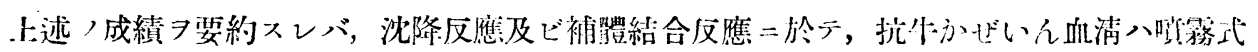

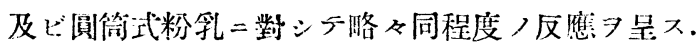

第 6 節抗牛乳清血清, 喷雾式及ビ渞简式粉笔

ニ對スル反應

笴 13 表 抗牛乳清血清, $\mathrm{Me}, \mathrm{K}, \mathrm{Mo}$, 及ビ L 粉乳

二對スル沈降反應

\begin{tabular}{|c|c|c|c|c|c|c|}
\hline $\begin{array}{l}\text { 稀釋倍數 } \\
\text { 抗原 }\end{array}$ & 800 & 1600 & 3200 & 6400 & 12800 & 25600 \\
\hline $\mathrm{Me}$ & + & + & - & - & - & - \\
\hline $\mathrm{K}$ & + & + & \pm & - & - & - \\
\hline Mo & $?$ & - & - & - & - & - \\
\hline $\mathrm{L}$ & $?$ & - & - & - & - & - \\
\hline
\end{tabular}

第13表. 沈降反應二於テ, 抗牛乳血清、 Me 及ビ $\mathrm{K}=$ 對シテ 1,600 倍乃至 3,200 倍二於テ， 反應习是スレドモ，Mo 及ビL二對シテハ 800 倍ニ於テモ反雔明㬗ナラズ.

第 14 袁 抵牛乳清血清, $\mathrm{Me}, \mathrm{K}, \mathrm{Mo}$ 及ビ $\mathrm{L}$ 粉乳 二對スル補體結合反應

\begin{tabular}{|c|c|c|c|c|c|c|}
\hline 稀釋倍數 & 25 & 50 & 100 & 200 & 400 & 800 \\
\hline 抗原 & $\mathrm{me}$ & $\mathrm{m}$ & $\mathrm{fk}$ & $\mathrm{K}$ & $\mathrm{K}$ & $\mathrm{K}$ \\
$\mathrm{K}$ & $\mathrm{m}$ & $\mathrm{fk}$ & $\mathrm{K}$ & $\mathrm{K}$ & $\mathrm{K}$ & $\mathrm{K}$ \\
$\mathrm{Mo}$ & $\mathrm{fk}$ & $\mathrm{fk}$ & $\mathrm{K}$ & $\mathrm{K}$ & $\mathrm{K}$ & $\mathrm{K}$ \\
$\mathrm{L}$ & $\mathrm{K}$ & $\mathrm{K}$ & $\mathrm{K}$ & $\mathrm{K}$ & $\mathrm{K}$ & $\mathrm{K}$ \\
\hline
\end{tabular}

第14表. 補體結合反應二於テ, 抗牛乳清血清入 $\mathrm{Me}$ 及ビ $\mathrm{K}=$ 對シテ弱度乍ラ反應ヨ呈ス レトモ, Mo 及ビ $\mathrm{L}=$ 對シテ八極メテ微弱ナル反應ヨ辛りジテ認メ得ルカ, 或八反應习認 メズ.

上述ノ成績ヨ要約スレバ，沈降反應及ビ補體結合反應ノ何レニ於テモ，抗牛乳清血清八梹 蓩式粉乳: 對シテ比較的明カナル反應 ヨ呈スルニ反シ, 圓䇠式粉乳二對シデハ殆ト反應 ヒズ.

第 7 節 抗煮沸牛乳血清ノ噴霧式及ビ圆筒式粉乳

$$
\text { 二對スル反隹 }
$$


宮川敬泟

(1125)

第 15 表 抗募沸牛:乳血清, $\mathrm{Me}, \mathrm{K}, \mathrm{Mo}$ 及ビ $\mathrm{L}$ 粉乳

二對スル沈降反隹

\begin{tabular}{|c|c|c|c|c|c|c|}
\hline 抗原 & 800 & 1600 & 3200 & 6400 & 12800 & 25600 \\
\hline $\mathrm{Me}$ & + & + & + & + & + & - \\
\hline K & + & + & + & + & + & - \\
\hline Mo & + & + & + & + & + & - \\
\hline $\mathrm{L}$ & + & + & + & + & \pm & - \\
\hline
\end{tabular}

第15表. 沈降反應二於テ, 抗煮沸牛乳血清入 $\mathrm{Me}, \mathrm{K}, \mathrm{Mo}$ 及ビ $\mathrm{L}=$ 對シテ略从同程度， 反應习呈ㅈ.

第 16 表 抗劣沸牛乳血清, $\mathrm{Me}, \mathrm{K}, \mathrm{Mo}$ 及ビ $\mathrm{L}$ 粉乳 =對スル 補體結合反應

\begin{tabular}{|c|c|c|c|c|c|c|c|c|c|}
\hline 执原 & 100 & 200 & 400 & 800 & 1600 & 3200 & 6400 & 12800 & 25 \\
\hline $\mathrm{Me}$ & 0 & 0 & $\mathrm{O}$ & 0 & $O$ & O & $\mathrm{O}$ & $\mathrm{m}$ & $\mathrm{st}$ \\
\hline K & 0 & 0 & 0 & 0 & 0 & 0 & spch & $\mathrm{m}$ & $\mathrm{fk}$ \\
\hline Mo & 0 & 0 & O & 0 & O & 0 & spch & $w$ & st \\
\hline $\mathrm{L}$ & 0 & 0 & O & 0 & 0 & spch & $\mathrm{sp}$ & $\mathrm{m}$ & $\mathrm{fk}$ \\
\hline
\end{tabular}

第16表. 補體結合反應二於テ, 抗煮沸牛乳血清, $\mathrm{Me}, \mathrm{K}, \mathrm{Mo}$ 及ビ $\mathrm{L}=$ 對入ル反應二大 差フ認メズ.

上述, 成績习通覽スル二, 沈降反應及ビ補體結合反應二於テ, 抗者沸牛乳血清八噴蓩式及 ビ湖简式粉乳二對シテ略从同程度, 反應》是不。

第 8 節 抗噴霧式粉孚及ビ抗圓筒式孚血淸ノ牛血清

$$
\text { 二對スル反應 }
$$

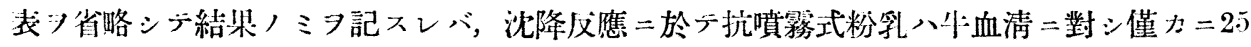
倍二於テ反應习認ムルノミ。

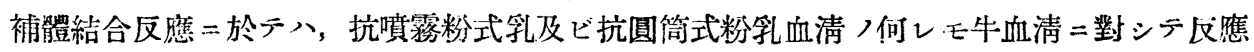
ヨ呈セズ.

\section{第 3 章總括並二考按}

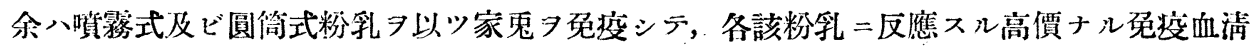

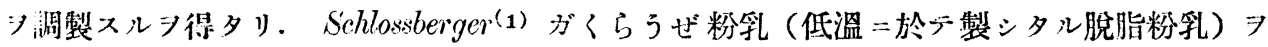

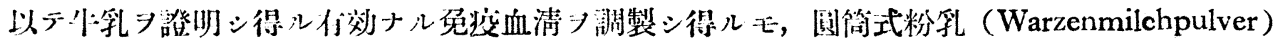


(1126)

八其 /製造過程二於テ高熱 ヨ作用セシメラルル結果免疫作用ヨ示サズト述バシガ，余）望驗

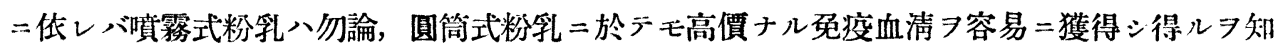
r.

福田(2) 八補體結合友應二於テ，抗生乳汁及ビ抗煮沸乳汁血清ノ各種粉乳二對スル反㷳 試ミ, 可檢品，大部分八生, 者沸兩乳孜疫血清ニヨク反應シテ補體結合價 $=$ 大差ラ認ムルコ ト能ハザレドモ，らくとーげん及ビきのみーるノ2 種八煮沸乳冤疫血清二八對照/自製煮沸 乳末溶液卜約同一力價フ示シタルモ，生乳免度血清二於ダル反應價八對照二比シ少シク劣ル 成績ヨ示シタリ.之ヨ以テ制ズルニ，各可檢品八乾燥二際シ何レモ, 加熱ヨ與へラレシモ, 其，溫度八生，煮兩免疫血清ニヨク反應スル程度ナリシガ，らくとーげん及どきのみーる， 2 秏八稍々高熱二失シタルカ, 或八加熱時間永カリシモノナルバシト論ジタリ。余八沈降反

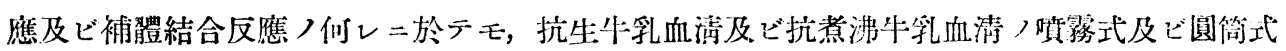

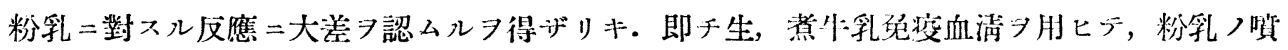
蓩式ナリヤ，或八圓筒式ナリヤア制定スルハ困難ナリ。

沈降反應及ビ補體結合反應二於テ, 抗噴霧式粉乳血清八損蓩式及ビ圆筒式粉乳 =對シ, 略

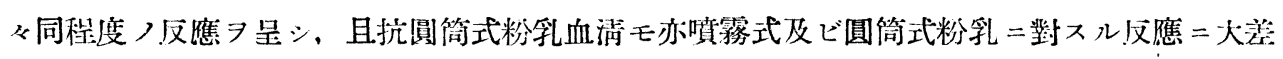
フ認メズ.

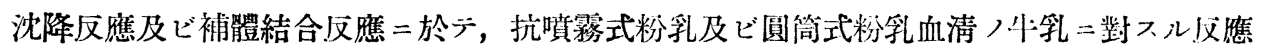

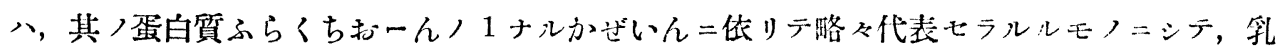
清八殆ド關與ヒザルモノナリ。

沈降反應及ビ補體結合反應二於テ，抗牛かぜいん血清八噴蓩式及ビ圆阿式粉乳二對シ略々

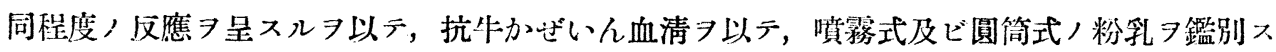
ルハ殆ド不可能ナリ。

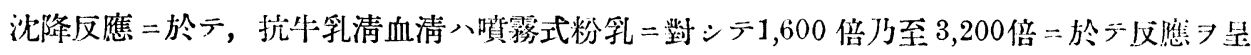
ハルニ反シ，圆筒式粉乳二對シテハ 800 倍ニ於テモ反應明嘹ナラズ．而テ補體結合反應二於

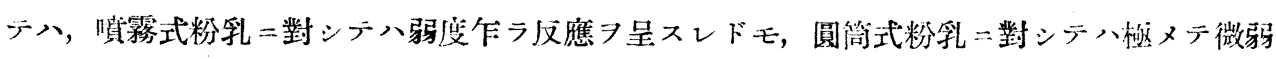
ナル反應タ辛ッジデ認メ得ルカ，或八反應セで，即千血清學的二粉乳，䫏霧式ナリけ，或八 圓筒式ナリヤフ辨ゼント行スレバ, 抗牛乳满血清ノ該粉乳二對スル反應度ラ檢スルフト可ス バシ.

沈降反應 $=$ 於テ, 抗噴蓩式粉乳血清ハ牛血清 $=$ 對シ 100 倍二於テ反應陽性ナル =反シ，抗

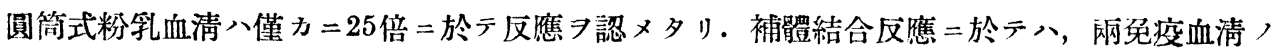
何レモ牛血清二全然反應ク見ズ. 


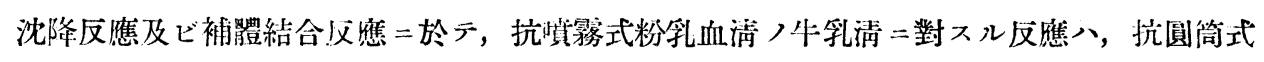
粉乳血清, 場合 $=$ 比シテ著明ナル事貴, 沈降反應及ビ補體結合反應, 何レニ於テモ, 抗牛乳

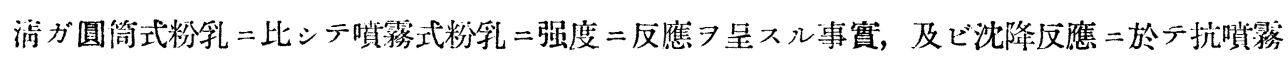
式粉乳血垌ガ抗[i]简式粉乳血清二比シテ牛血清二對シ高度二反應シ得儿事實等八總テ噴霧式

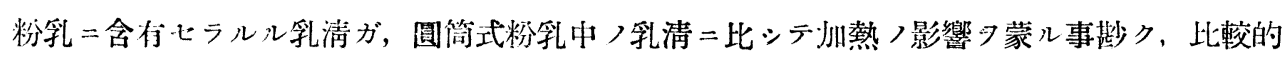

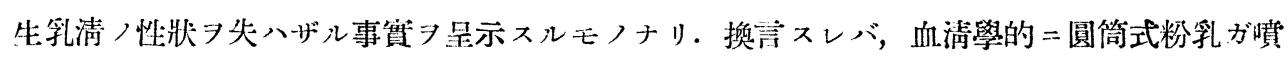
攃式粉乳二比シテ，其，製造過程二於テ比較的高熱 ノナリ.

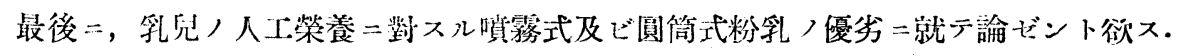

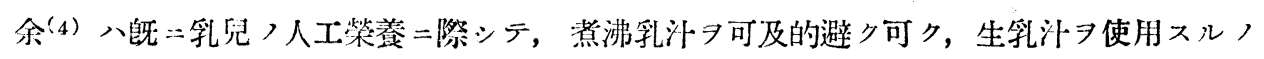

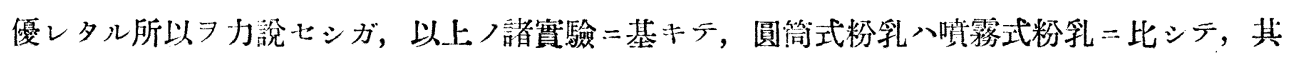

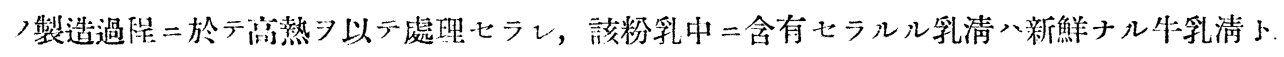

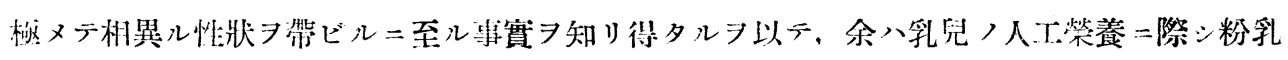
フ使朋スル，止么無キ二至ラバ，圆简式粉乳 ルタ强調ヒント欲ス.

\section{結論}

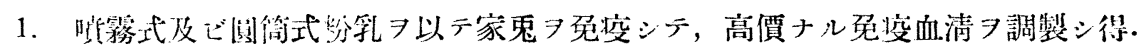

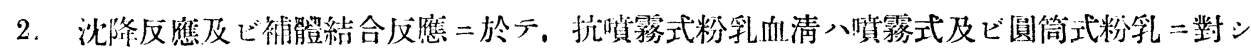
テ略々同程度, 反應 9 呈不.

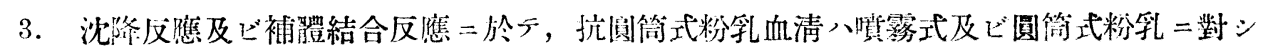
テ略々同程度, 反應》是下。

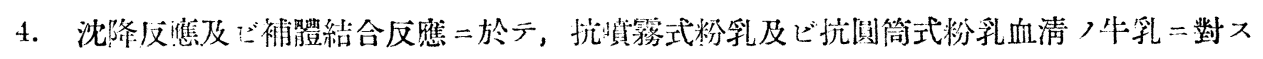
ル反應八，其ノ蛋白質ふらくちお゙ーんノ1ナルかぜいん=對スル反憵=依りテ代表ヒラルル

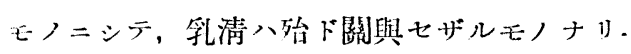

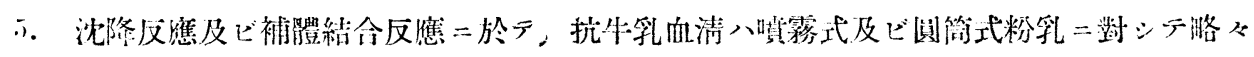

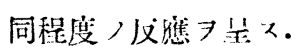

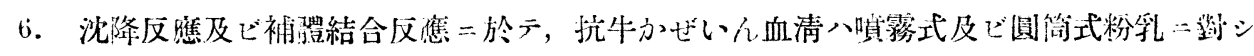
テ略的同程度, 反應》是无。

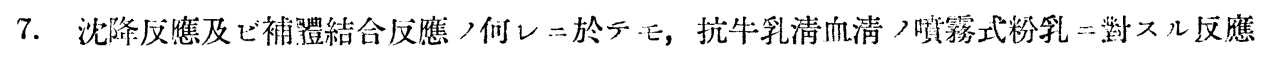

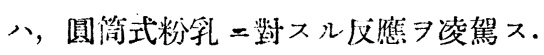

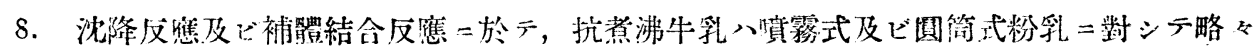


(1128)

同程度ノ反應 $习$ 呈ス。

9. 抗噴籍式粉乳及ビ抗圓筒式粉乳血清八何レモ沈降反應 $=$ 於テ低度乍ラ牛血清 $=$ 反應 呈スレドモ，前者〉牛血清二對スル反應八後者 $\curlywedge$ 牛血清二對スル反應 $=$ 比シテ稍々著明ナリ. 補體結合反應ニ於テハ, 兩抗血㳙ハ共二牛血清ニ對シテ反應 7 認メズ.

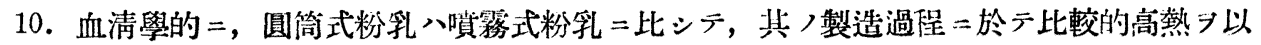
テ處理七ラルルモノナル 推知シ得.

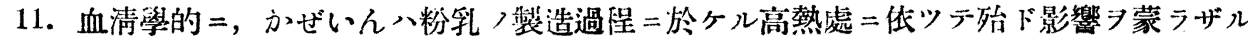
二反シ, 乳清八湛大ナル變質

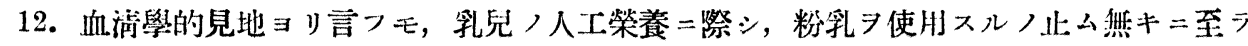
バ，須ク貲蔡式粉乳 7 月フル 可トナス。

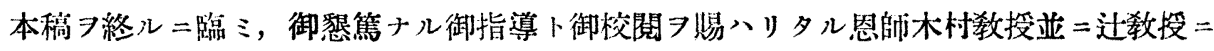

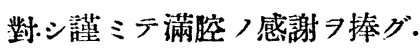

\section{主 要 文 献}

1) Schlossberger, Reichsgesdh. bl. 1934, 84-87. cit. n. Centralb. f. Bakt. 1934, Bd 114, Bef.

2) 楅田, 臺灣醫學會雜誌, 昭和10年5月, S. 644 .

3）宮川; 日本微生物學病理學雜誌, 昭和12年 2 月, S. 160.

4) 宮川，日本微生物學病理學雜誌，昭和12年4月，S.479及6月S.1085.

5）宮脇, 兒科雜声，昭和 5 年，S. 1783，兒科雜誌，昭和 6 年，S. 1682.

6) 戥井，兒科雜誌，昭和 6 年，S. 371, S. 577 , S. 1140, S. 1.226.

7) 毁尾 及ビ共同者, 乳兒學雜請，昭和 9 年, 7 月, S.1 